Journal of Advanced Research in Fluid Mechanics and Thermal Sciences

Journal homepage: www.akademiabaru.com/arfmts.html ISSN: 2289-7879

\title{
Photovoltaic Potential Analysis - Fuel Cell Hybrid Energy System for General-Purpose Building of Laboratory and Offices Using HOMER Software
}

\author{
Sivachandran R. Perumal ${ }^{1}$, Faizal Baharum ${ }^{1,}{ }^{*}$, Mohd Nasrun Mohd Nawi ${ }^{2}$, Mohd Faizal Omar $^{3}$ \\ School of Housing, Building \& Planning, Universiti Sains Malaysia, Gelugor, Penang, Malaysia \\ School of Technology Management and Logistic, Universiti Utara Malaysia, Sintok, Kedah, Malaysia \\ School of Quantitative Sciences, College of Arts and Sciences, Universiti Utara Malaysia, Sintok, Kedah, Malaysia
}

\section{ARTICLE INFO ABSTRACT}

\section{Article history:}

Received 29 March 2021

Received in revised form 1 June 2021

Accepted 9 June 2021

Available online 16 July 2021

\section{Keywords:}

Hybrid power systems; renewable energy; fuel cells; photovoltaic; HOMER; grid-connected; energy saving

\begin{abstract}
This paper presents a performance analysis of the potential study in complementing grid utility supply with the renewable energy system. A general-purpose building consisting of an office and laboratory facility has been chosen as a test case with a hybrid system of fuel cell and solar photovoltaic cells installed in addition to the existing grid power supply. HOMER simulation software was used to run the simulations, and the results showed that only the photovoltaic system is more economical to be integrated into the system. Cost-saving from the feed-in-tariff point of view was observed spanning over several years after the initial capital cost was returned.
\end{abstract}

\section{Introduction}

Electrical power is an essential energy source component in developing countries such as Malaysia. According to the Energy Commission of Malaysia, the electrical power consumption of commercial, industrial, and residential sectors is on the rise annually [1]. Energy consumers were divided into five sectors, as shown in Figure 1. The latest report published in 2018 for the year 2016 showed a shift in energy consumption whereby the transportation sector consumed the most compared to the early 2000s, whereby the industrial sector was the most significant consumer [2]. The shift in energy use is illustrated in Figure 2.

In developing countries, commercial buildings such as retails, warehouses, and offices are built for the city's growth. The impact of rapid development causes more use of raw fuel, as shown in Figure 3. In the mid-nineties, petroleum products were the primary source of energy production $[1,2]$. However, with the advent of science and technology, different fuel type was used for energy harvesting. Petroleum-based fuel was less used in the twentieth century.

\footnotetext{
* Corresponding author.

E-mail address: baharumfaizal@gmail.com
}

https://doi.org/10.37934/arfmts.84.2.6381 


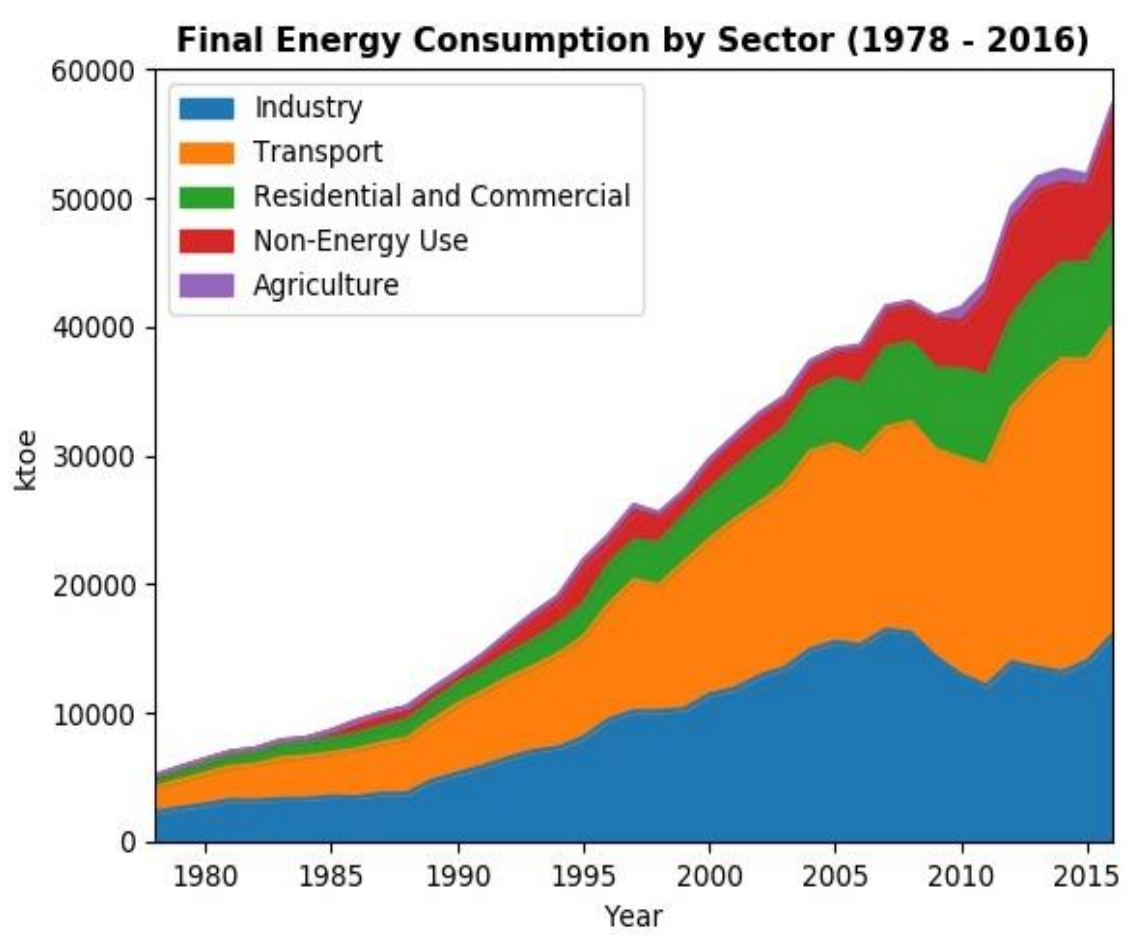

Fig. 1. Final energy consumption by sector (1978-2016)

\section{Energy Consumption By Sector (Mtoe)}

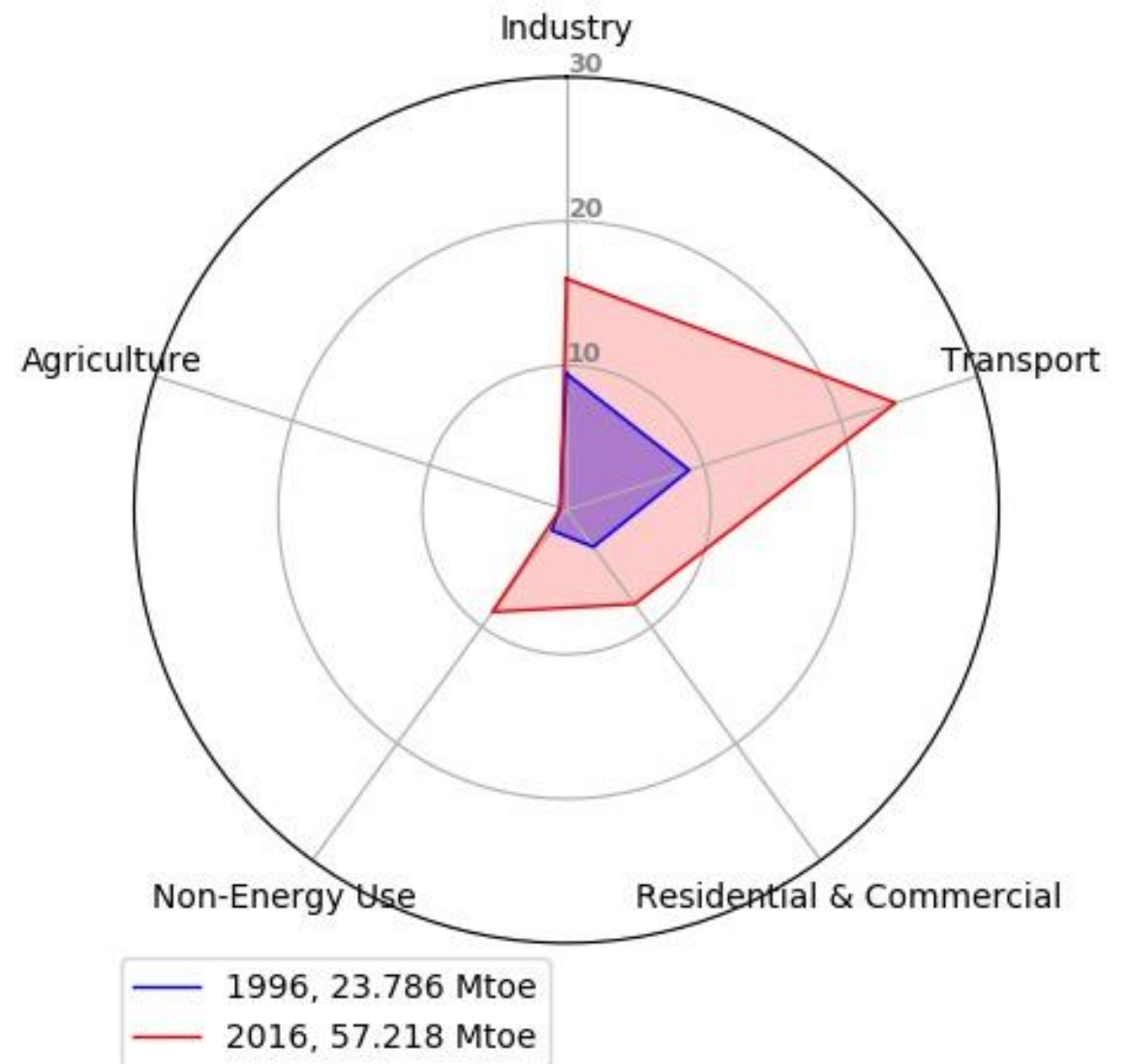

Fig. 2. Chart of energy consumption by sectors (1996 vs 2016) 


\section{Energy Consumption by Fuel Type (Mtoe)}

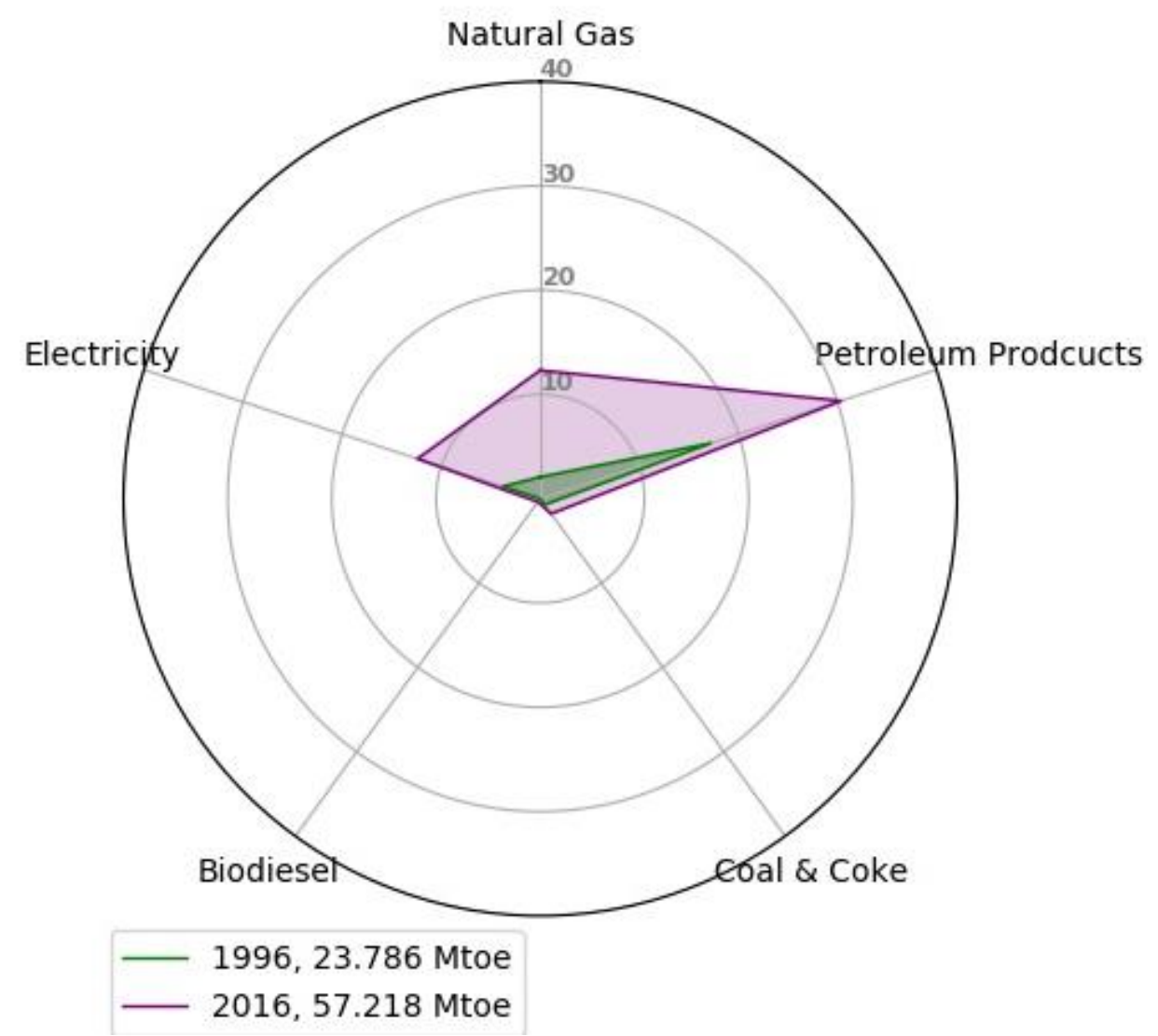

Fig. 3. Chart of electricity consumption by fuel type (1996 vs 2016)

The shift in petroleum-based products to the likes of electricity (e.g., hydropower plant), natural gas, and others is due to the ever-diminishing earth's raw fuel [3]. This phenomenon has led to scientists and engineers investing and researching into developing generating systems that utilize fuels such as natural gas, biodiesel, and others. Of these many technologies, fuel-cell and photovoltaic systems are some of the rising technologies for electrical energy generation [4].

\subsection{Objectives of the Study}

The objectives of this study are to find out: (a) whether a hybrid of photovoltaic (PV) and fuel cell system can be used to support a partial load of an office building during day and night time; (b) what is the cost of this system; and (c) whether it is cost-effective for installations and operations as compared to existing grid source support only.

\subsection{Fuel Cells}

There are four major components in the fuel cell system: fuel cell stack, fuel processor, current inverter and conditioners, and heat recovery system. Modern and complete fuel cell systems integrate subsystems to manage temperature, cell humidity, and internal gas pressures [5]. The fuel cell stack is the gist of a fuel cell power system. Chemical reactions within the system generate electrical energy in the form of direct current (DC). A single fuel cell can generate higher output with an efficiency of $60 \%$ or more than conventional combustion engines, which rates at circa $40 \%$ [5]. Therefore, fuel cells are cascaded for larger loads, perhaps cities. 
Industrial grade fuel cell stacks consist of hundreds of single fuel cells. Factors such as cell type, operating temperature, and pressure determine its power production capability. The fuel processor converts raw chemical potential energies into a suitable type. If Hydrogen is directly fed to the system, a processor (reformer) may not be required or may only act as an input gas filter [5]. Typically, a reformer must extract pure hydrogen gas when biogas such as methanol, gasoline, diesel, or gasified coal is fed in at the input side. An additional filtering process may be needed to purify the reformer's output. Internal and external reformers release carbon dioxide, but less than the amount emitted by internal combustion engines, such as those used in gasoline-powered vehicles. Figure 4 below illustrates that when hydrogen molecules enter the fuel cells, they are ionized due to chemical imbalance. The free electrons are used to create current flow.

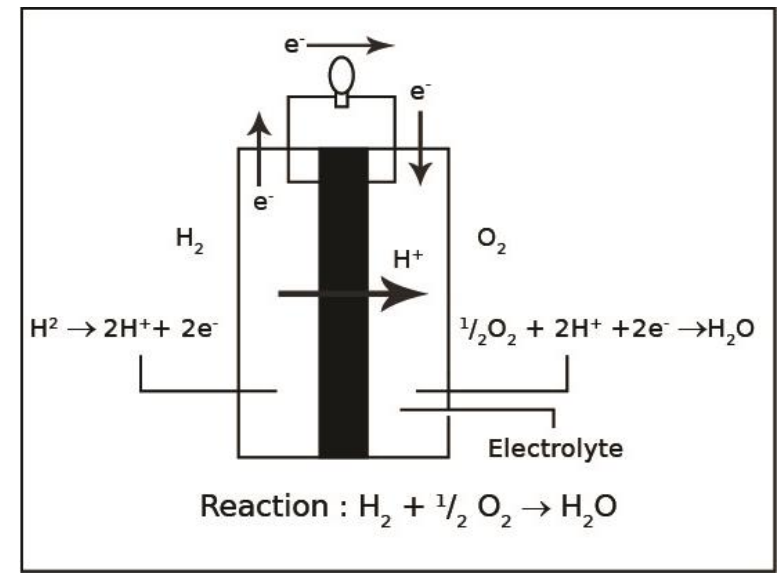

Fig. 4. Fuel cell chemical operation

With the power electronics, current inverters and conditioners adapt the electrical DC output from the fuel cell to supply specific electrical application needs. Most of our electrical equipment needs DC to operate. Due to high losses in electrical power transmission lines, power is transmitted in alternating current $(A C)$ and rectified to $D C$ in equipment. Both $D C$ and $A C$ power must be conditioned, i.e., brought down to an acceptable level of voltages and waveforms. Power conditioning comprises regulating current flow, voltage, frequency, and others to meet the end needs of the application. Power losses are associated when conversion and conditioning are done, usually result in reduced system efficiency, around $2 \%-6 \%$ [6].

Significant quantities of heat are generated by some fuel cell systems, especially those that operate at high temperatures, such as solid oxide and molten carbonate systems. Excess energy can be used to produce steam and hot water to be converted to electrical energy via a gas turbine or other technology through the side products of the fuel cell. These methods, named heat exchange and recovery, increase the system's overall energy efficiency [7-9].

\subsection{Photovoltaic Cells}

Photovoltaic cells, more commonly known as PV cells, have generated electrical power since the early eighties. However, due to the high cost per power ratio at those times, the ventures into utilizing PV cells were less. In the late nineties and two thousand years onwards, again with the advent of power electronics, electrical power could be harnessed at acceptable efficiency with a lower cost per power ratio [10].

The concept of power generation from PV cells lies in the energy conversion from light to electrical. Solar panel's working principle is by allowing light (photons) to disengage electrons free 
from atoms, generating a flow of current when biased to a potential difference $[4,10,11]$. Solar panels comprise many smaller units called photovoltaic cells. When enough cells are arranged in series, it would be possible to power loads in the ranges of kilowatts.

As shown in Figure 5, when light hits the solar panels, which consist of photovoltaic cells, an imbalance of electrons is created in the semiconductor device, which eventually generates a flow of electrical current due to a difference in potential energy.

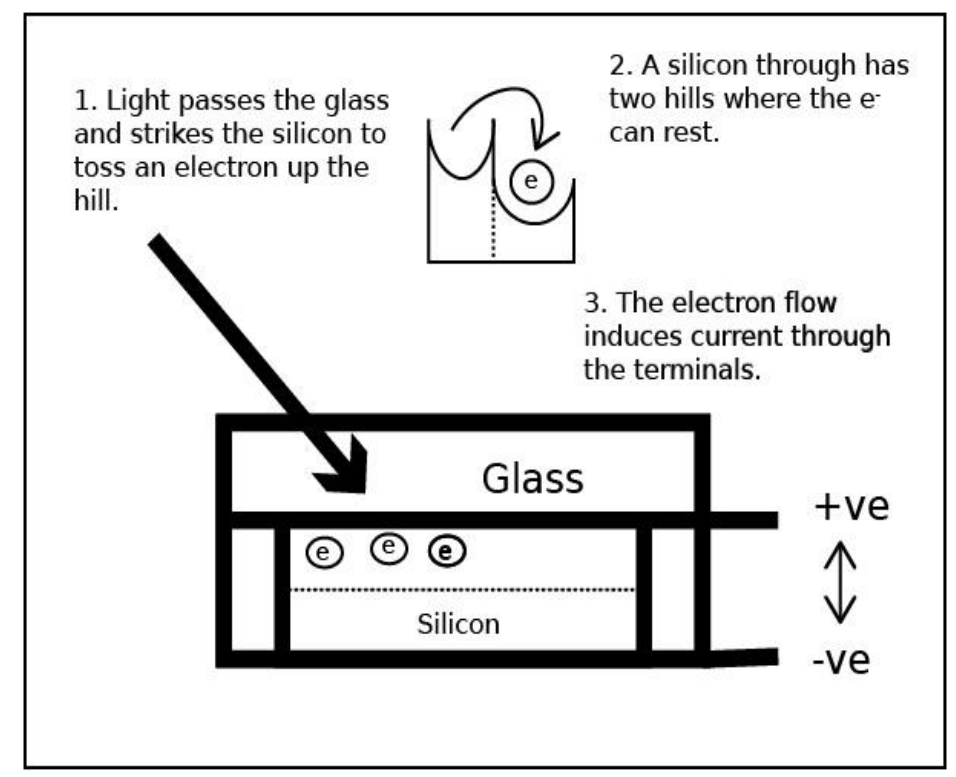

Fig. 5. PV cell operations

\subsection{Photovoltaic and Fuel Cell Hybrid System}

There is a long list of hybrid systems that have been researched and tested in the market. The results obtained from those researches are encouraging. According to Rahman and Tam [12], using the hybrid system between PV and fuel cells is feasible. The combination can overcome the intermittency problems inherent with PV, and this alone will make PV electric power generation more feasible. According to Rajashekara [13] and Khattak et al., [14], the hybrid system between PV and Fuel Cell can be used in both stand-alone power generation and transportation applications. The major drawback highlighted by the author is the commercialization of this hybrid system. The initial cost for the hybrid system is very high. Wang and Nehrir [15] and Khattak et al., [16] highlighted the effectiveness and flexibility of the hybrid system. PV will act as the primary power generation, and fuel cell acts as a backup generator and supplies power to the system when there is a power deficit. Some most recent papers presented by Trifkovic et al., [17] and Bakri et al., [18] suggested that to improve and fully utilize the hybrid system, a predictive controller has to be added into the system. The predictive controller will significantly improve the system's composition and make better the power management of the hybrid energy system.

\subsection{HOMER Software}

National Renewable Energy Laboratory (NREL) of the United States (US) Department of Energy developed software HOMER. In this study, HOMER Version 2.68 beta is used to optimize the design work. The advantage of HOMER is early screening and assessment of a potential project with detailed data before proceeding to design and construct the project. With the aid of HOMER, facility 
managers, program planners, project developers, and technology developers can define a costeffective renewable system with a suitable size of storage to reduce the effort of studying detailed engineering design [11]. Simulation, optimization, and sensitivity analysis can be done by using HOMER software. Modelling the system and feasible study is part of the simulation process. Optimal system configuration selection is performed in the optimization process. Multiple optimizations for model input uncertainty will be carried out by the sensitivity analysis process [12].

\section{Background of Study}

A building named $\mathrm{KM} 3$ is a general-purpose facility located in Kulim Hi-Tech Park, Kedah (Malaysia), and has a building size of $195,624.63 \mathrm{ft}^{2}$. A US-based multinational company operates the building. Outside the building, open parking with no roof has a floor area of $234,178 \mathrm{ft}^{2}$. This building is built on two floors. The ground floor of the building accommodates varieties of labs, Cafeteria, gymnasium, cooperative store, library, lobby, IT server room \& Facility plant room. Level 1 accommodates two general offices (East wing \& West wing), meeting rooms, training rooms, and facility AHU rooms. This building is chosen in this study to take advantage of the flat rooftops and the vast open car parking spaces, where PV cells may be laid out.

In general, electrical capacity is designed to support maximum building's load in a day. The building load starts at 7 a.m. when people arrive at the office and lab to start their daily work. The electrical consumption will achieve peak demand from 11 a.m. to 3 p.m. Weather in Malaysia, which can reach an ambient temperature of 90 degrees Fahrenheit after 1 p.m., continue to stretch the electrical consumption to the maximum point. The building load experiences a dramatic decrease after 6 p.m. as people leave the office. The electrical consumption at night is maintained at a low side with minimum numbers of people, lighting, and equipment running. The electrical consumption of the weekend is slower than a weekday. It is reasonable because of the low heat load during nonworking days, and the machine in the lab is in idling mode with little quantity of heat generated. Figure 6 shows KM3's load profile for a twenty-four-hour cycle.

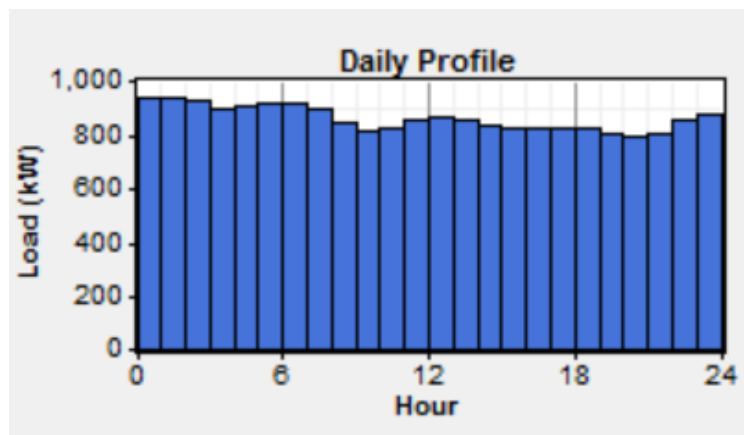

Fig. 6. KM3 load profile

Electric utility provider will define "on-peak," which is 8.01 a.m. - 9.59 p.m. and "off-peak," which is 10.00 p.m. - 8.00 a.m. rate to end-users. As an encouragement of electric consumption reduction during peak demand, the rate of "off-peak" is lower than the "on-peak" rate. Nevertheless, many end users still have to pay the high "on-peak" rate to the electric utility provider to run their business. Another component of the electric utility rate is maximum demand, which is defined as the highest energy draw by the building to support their business on any day of a month. The end-users will have to pay on top of their monthly electric consumption for the maximum demand. This maximum demand is considered a premium rate. Figure 7 shows KM3's average load profile summarised from 
a kWh (energy) and maximum demand (kW) point of view. Table 1 shows the utility's energy tariff rating, which applies to the $\mathrm{KM} 3$ building.

\begin{tabular}{|l|r|r|} 
& Baseline & Scaled \\
\hline Average $(\mathrm{kW} / \mathrm{h} / \mathrm{d})$ & 20,006 & 20,006 \\
\hline Average $(\mathrm{kW})$ & 834 & 834 \\
\hline Peak $(\mathrm{kW})$ & 1,952 & 1,952 \\
\hline Load factor & 0.427 & 0.427 \\
\hline
\end{tabular}

Fig. 7. KM3 load summary

Table 1

Tariff used by the KM3 office building

\begin{tabular}{ll}
\hline Tariff E2-Medium Voltage Peak/Off-Peak Industrial Tariff & Rates (1st Jan 2014) \\
\hline $\begin{array}{l}\text { For each kilowatt of maximum demand per month during the } \\
\text { peak period }\end{array}$ & $37.00 \mathrm{RM} / \mathrm{kW}$ \\
For all kWh during the peak period & $35.50 \mathrm{sen} / \mathrm{kWh}$ \\
For all kWh during the off-peak period & $21.90 \mathrm{sen} / \mathrm{kWh}$ \\
The minimum monthly charge is RM 600.00 & \\
\hline Source: Tenaga Nasional Malaysia &
\end{tabular}

PV system, which will be designed, is the main target for reducing the impact of a high "on-peak" rate in the daytime, while fuel cells can be fully utilized to support low electric consumption during nighttime. Hydrogen, which is classified as the cleanest carrier of energy globally, can be used in a fuel cell to generate electricity.

\section{Methodology}

Simulation work was started by identifying a hybrid renewable energy system. The hybrid of photovoltaic and fuel cell energy systems is the initial conceptual design of this study. Electric demand by an hour of weekday and weekend for a year was collected from the electrical sub-meter. It had been verified with the monthly bill charged by the local utility providers. The load demand of the office building is shown in Figure 8 below. The office load has been scaled to $20,000 \mathrm{kWh} /$ day, and peak load is recorded at $19.5 \mathrm{MW} /$ peak. The estimated lifetime is set to 25 years, while the annual interest rate is fixed at $6 \%$.

There are two components of day-to-day variability and time-step-to-time variability in random variability factors. After electrical data of building is input into the simulation software, day-to-day time-step-to-time and variability show approximately $15 \%$ and $20 \%$, respectively.

From the HOMER software, authors can estimate the Net Present Cost (NPC) of the system, including the total cost of installation and operation of the system over its lifetime. 


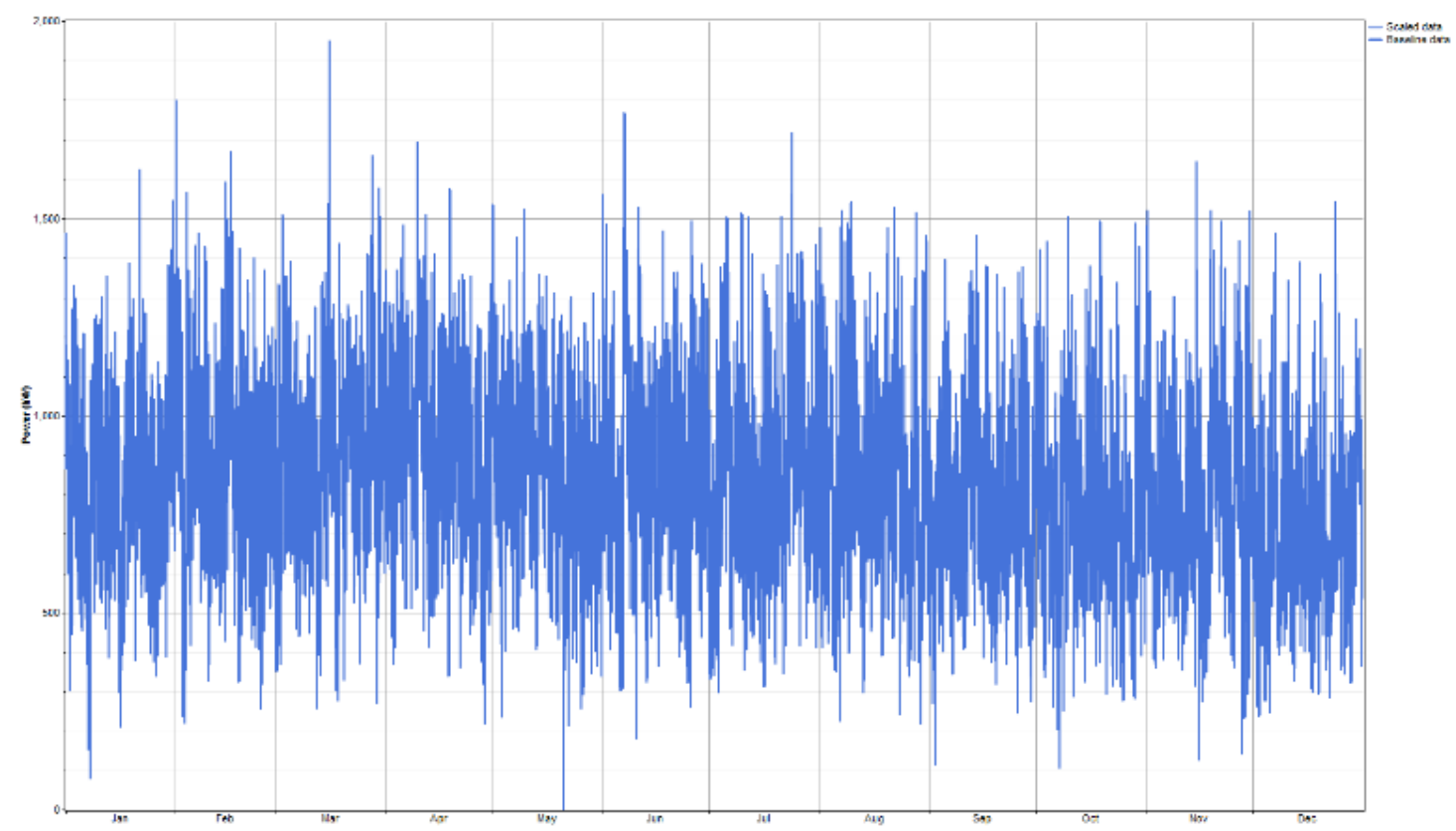

Fig. 8. Daily average load in a year for KM3

\subsection{Solar Source and Photovoltaic}

The latitude and longitude for the project location is $5^{\circ} 25^{\prime} \mathrm{N}$ and $100^{\circ} 35^{\prime} \mathrm{E}$, respectively. NASA Atmospheric Data Centre provided solar radiation data, and it is shown in Figure 9 below. NREL website provides the cost of PV cells to be included in this study as a preliminary approximate.

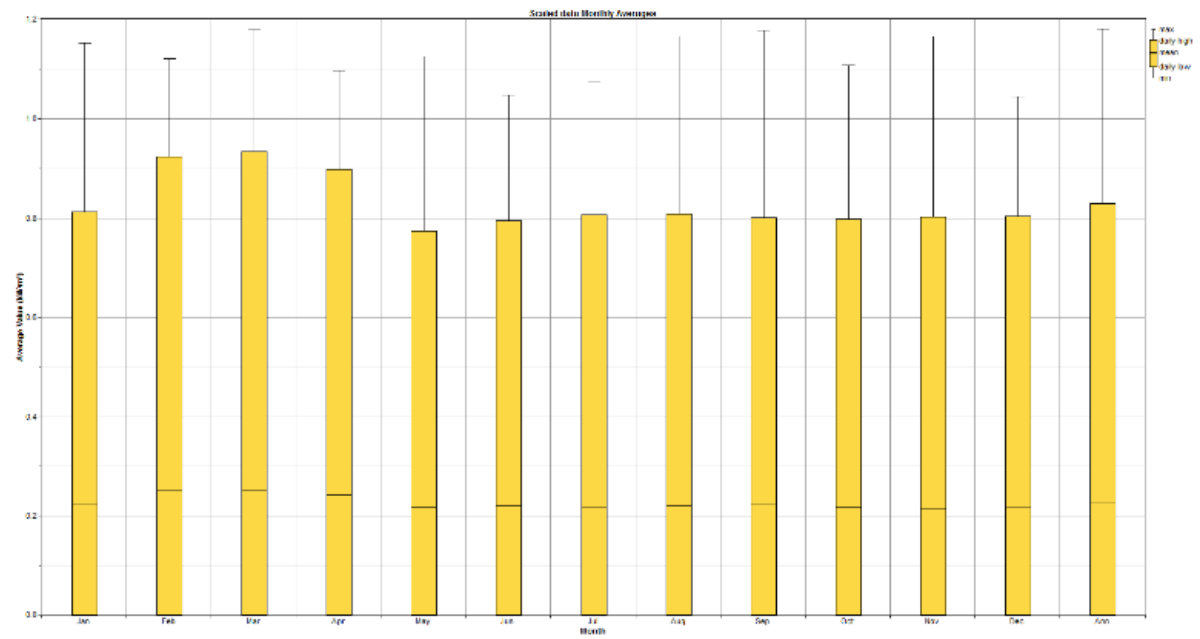

Fig. 9. Monthly average solar radiation

KM3 building compound area has a total of flat roof space of $195,624.63 \mathrm{ft}^{2}$, and open car park spaces are in the range of $234,178 \mathrm{ft}^{2}$. Thus, in total, there would be a PV cell installable space of $429,802 \mathrm{ft}^{2}$. By cutting corners on unusable areas due to traffic flows and building limitations, i.e., by taking only $70 \%$ of the area, it is only left with about $300,000 \mathrm{ft} 2$ space for PV installations.

Market research has shown that a single PV cell size is about $14 \mathrm{ft}^{2}$, with each capable of generating up to 240 Watts. Therefore, the maximum size of the PV cells and the converter shall be $300,000 \mathrm{ft}^{2} / 14 \mathrm{ft}^{2}$, which will be around 20,000 kilowatts. Table 2, 3, and 4 tabulate the input data applied to the HOMER software for the PV cell energy generation process. 
Table 2

PV cell input data

\begin{tabular}{ll}
\hline Input parameter & Input data \\
\hline Capital cost & $51,750 \$ / 100 \mathrm{~kW}$ \\
Replacement cost & $258750 \$$ \\
O\&M cost & $0 \$ / \mathrm{yr}$ \\
Array slope angle & $49^{\circ}$ \\
Array azimuth & $0^{\circ}$ refer to south direction \\
Lifetime & 25 years \\
De-rating factor & $70 \%$ \\
Ground reflectance & $20 \%$ \\
Options on size and unit numbers & $0,1800,1900,2000,3000,3100,3500,4500,5000 \mathrm{~kW}$ \\
\hline
\end{tabular}

Table 3

Fuel cell input data

\begin{tabular}{ll}
\hline Input parameter & Input data \\
\hline Capital cost & $3,000 \$ / 5 \mathrm{~kW}$ \\
Replacement cost & $2500 \$$ \\
O\&M cost & $0.08 \$ / \mathrm{yr}$ \\
Lifetime & $40,000 \mathrm{hrs}$ \\
Options on size and unit numbers & $0,500,600,900,1000,1500,2000 \mathrm{~kW}$ \\
\hline
\end{tabular}

Table 4

Converter input data

\begin{tabular}{ll}
\hline Input parameter & Input data \\
\hline Capital cost & $2,000 \$ / 50 \mathrm{~kW}$ \\
Replacement cost & $200 \$$ \\
O\&M cost & $100 \$ / \mathrm{yr}$ \\
Lifetime & 20 years \\
Efficiency & $95 \%$ \\
Options on size and unit numbers & $0,2000,2050,2100 \mathrm{~kW}$ \\
\hline
\end{tabular}

\subsection{Hydrogen Source}

Fuel cells run on hydrogen gas, where it has a simple molecule structure and is available in abundance. Hydrogen may exist in binary form, i.e., in liquid and solid states. In its purest forms, Hydrogen is the lightest element from the periodic table. However, its energy contained per unit weight is the highest of all fuels, where its energy per weight density is $52,000 \mathrm{BTU} / \mathrm{lb}$., which is three times more than that of gasoline or petrol.

Hydrogen is never found on its own. In a stable state, it always combines with other atoms such as oxygen or carbon. Figure 10 shows the molecular structure of Hydrogen. Hydrogen can be extracted from practically any hydrogen-containing compound, including both renewable and nonrenewable resources. Regardless of the fuel source, fuel cells produce no polluting emissions when utilizing Hydrogen. 


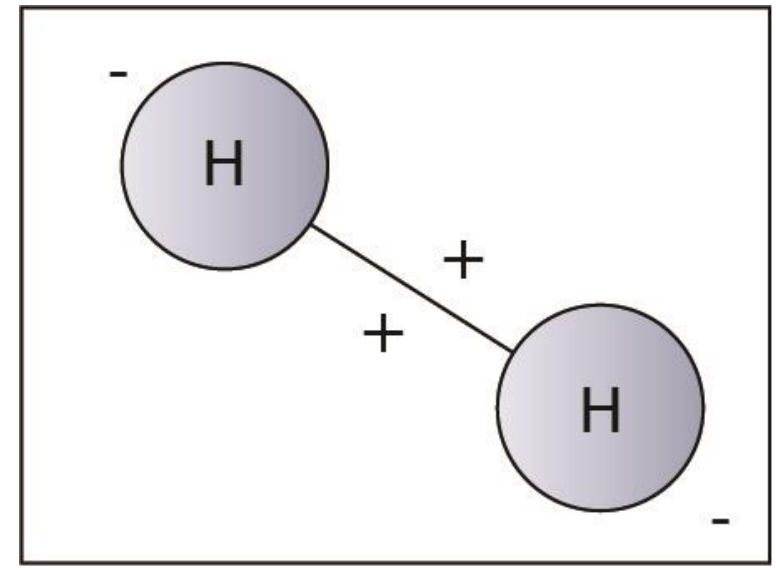

Fig. 10. Hydrogen molecule $\left(\mathrm{H}_{2}\right)$

In the US alone, Hydrogen is transported via 700 miles of pipelines without harm, and 70 million gallons of liquid Hydrogen is transported annually on land over US highways without incident. There are indoor and outdoor hydrogen refuelling stations are located in many states. They have safely dispensed compressed Hydrogen for use in passenger vehicles, buses, trucks, forklifts, and other types of vehicles.

Hydrogen is produced from a wide range of raw materials, and any hydrogen-rich material can serve as a potential fuel source for fuel cells. Hydrocarbon fuels, novel feedstocks such as landfill gas, anaerobic digester gas, and biomass can also produce Hydrogen, as can compounds containing no carbon, such as ammonia or borohydride. The vast majority of today's Hydrogen is produced via steam reformation of natural gas ( $95 \%$ in the US, roughly $48 \%$ globally), but alternative sources such as biogas are growing in popularity.

\subsection{Water Electrolysis}

When an electric current is introduced to water $\left(\mathrm{H}_{2} \mathrm{O}\right)$, hydrogen and oxygen atoms are detached, with Hydrogen forming at the cathode, whereas oxygen forming the anode. A simple setup of the electrolysis process is shown in Figure 11. There are various methods to introduce electric current to electrolyze water. Potential energy could be converted to electrical energy using renewable energies such as solar, hydro, and wind energy. However, a direct grid input to the electrolyzer was chosen to eliminate any conflicts and complexity in this study.

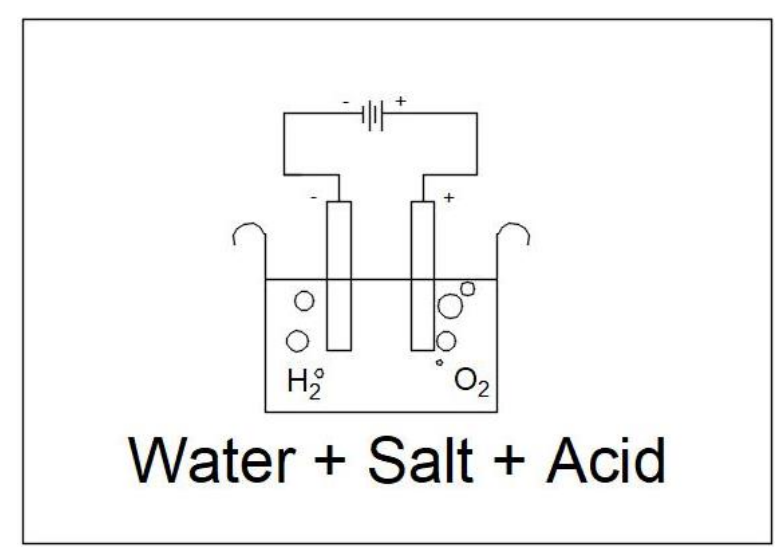

Fig. 11. Simple electrolysis set up 
Table 5 and 6 below tabulate the details entered into the HOMER simulation software for the water electrolysis process.

Table 5

Electrolyzer input data

\begin{tabular}{ll}
\hline Input parameter & Input data \\
\hline Capital cost & $1,000 \$ / 10 \mathrm{~kW}$ \\
Replacement cost & $100 \$$ \\
O\&M cost & $10 \$ / \mathrm{yr}$ \\
Efficiency & $80 \%$ \\
Lifetime & 15 years \\
Options on size and unit & $0,3400,3500,3600,3700$ \\
numbers & $\mathrm{kW}$ \\
\hline
\end{tabular}

Table 6

Hydrogen input data

\begin{tabular}{ll}
\hline Input parameter & Input data \\
\hline Capital cost & $1,000 \$ / 2000 \mathrm{~kg}$ \\
Replacement cost & $100 \$$ \\
O\&M cost & $10 \$ / \mathrm{yr}$ \\
Lifetime & 20 years \\
Options on size and unit & $0,955000,955500,955600$, \\
numbers & $956000 \mathrm{~kg}$ \\
\hline
\end{tabular}

\subsection{Block Diagram and Schematic Diagram}

The hybrid system may be configured by the separation of the $A C$ and DC link. The Block diagram in Figure 12 below illustrates the power flow from both links. Both links are interconnected by a power converter, i.e., the inverter.

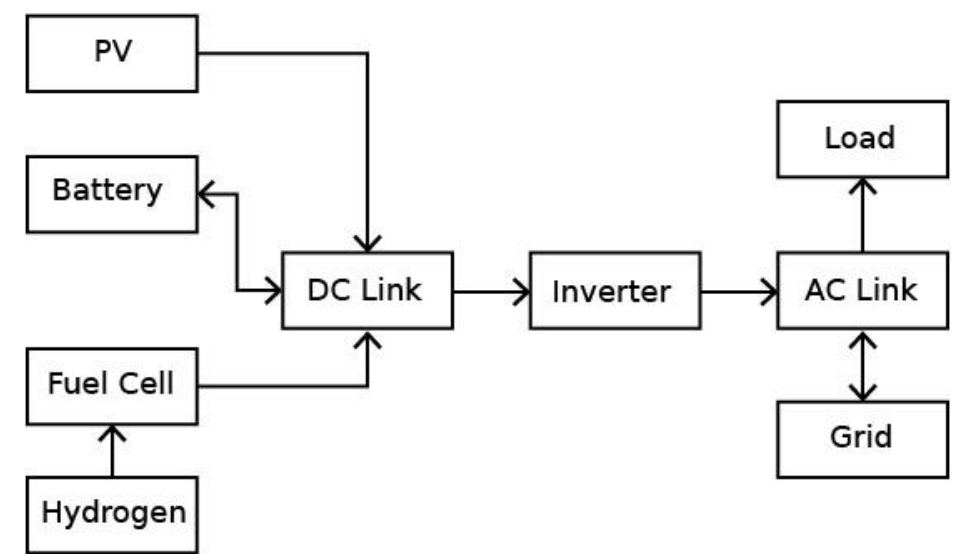

Fig. 12. Block diagram for simulation

Figure 13 below illustrates the connections of the hybrid system created in HOMER software. It consists of all the fuel-cell/photovoltaic hybrid systems mentioned in the review above. The systems also constitute a battery as a storage element and the utility grid. The concept adopted was to complement the grid supply for daily demand and feed the excess power generated back into the grid. 


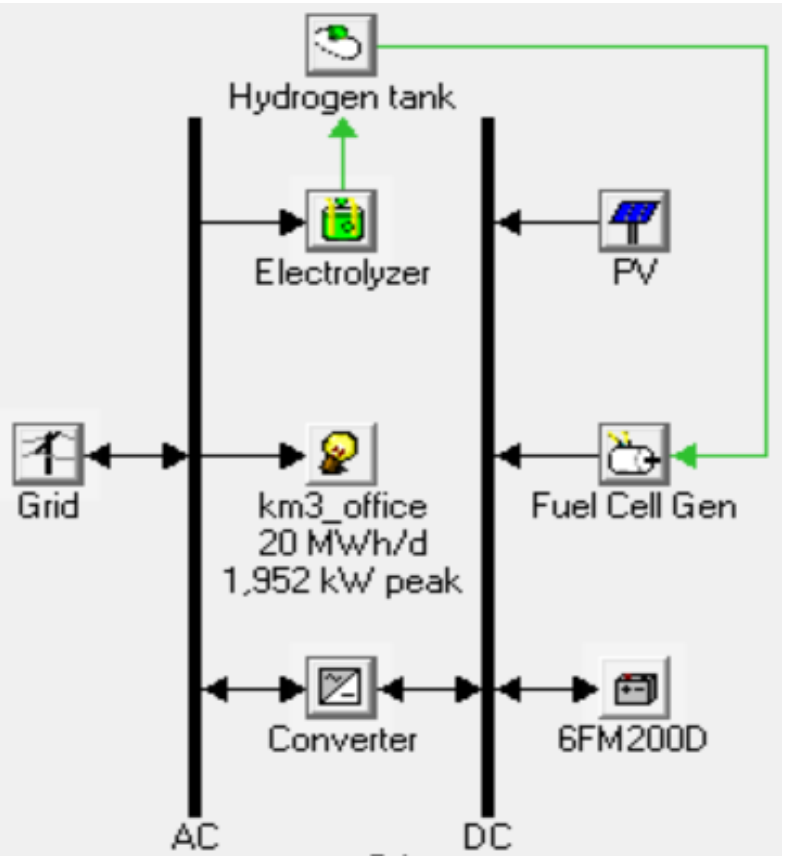

Fig. 13. Schematic diagram

\section{Results and Analysis}

When simulated in HOMER to yield the feasibility of such hybrid installations, it has been shown that the fuel cells are less utilized than the photovoltaic cells. The winning configuration has not used even a single $\mathrm{kg}$ of Hydrogen. This is due to the high capital cost of the fuel cell and less return of investment spanning over more extended periods. From a practical point of view, the storage of Hydrogen and pipeline may also be an inhibiting factor. In contrast, the photovoltaic cells may seem a more credible source by taking advantage of the nature of the building, which has flat rooftops and ample open parking space. The grid input was as follows in Figure 14, according to utility rates.

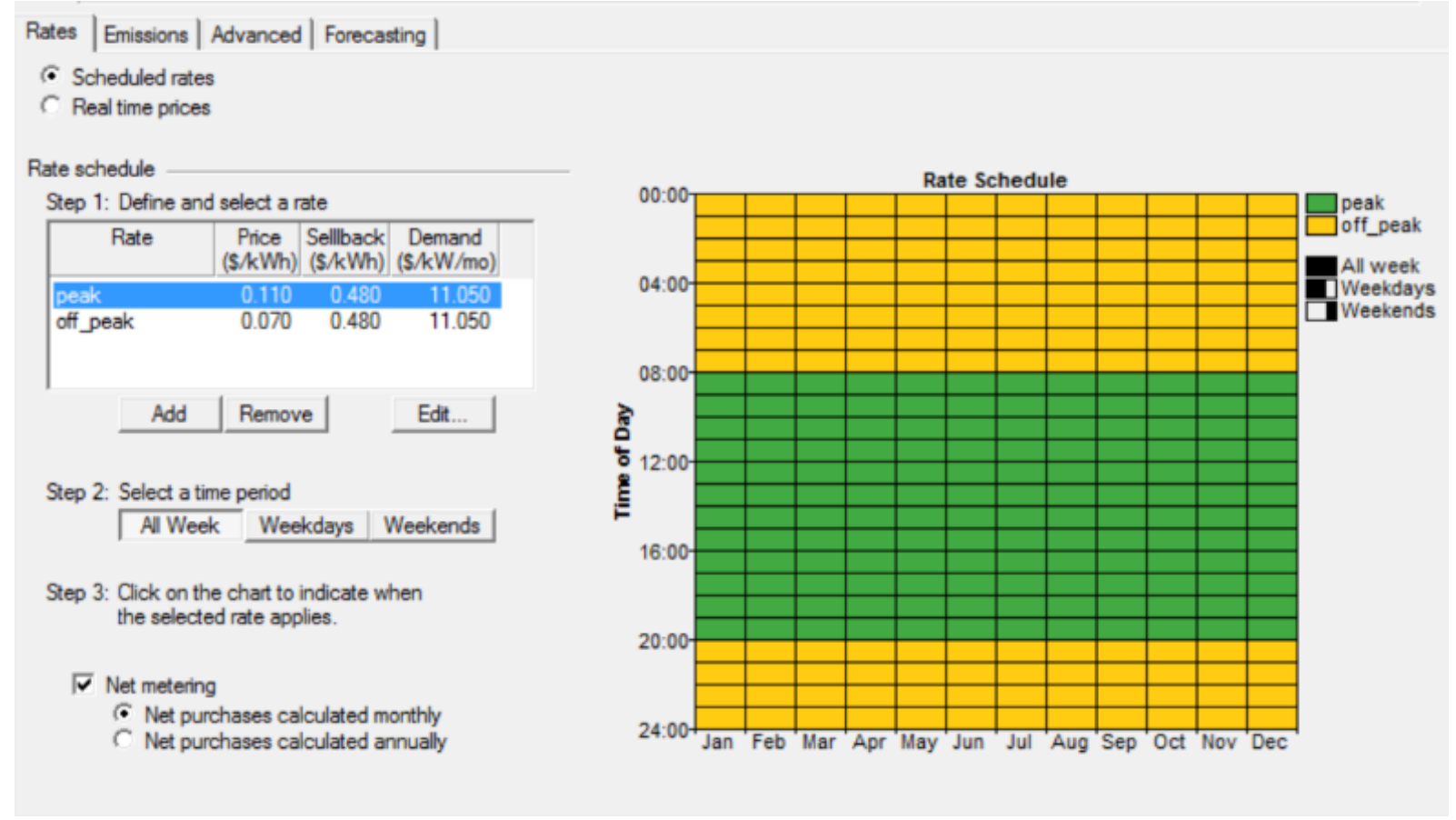

Fig. 14. Grid rate inputs 
A constraint forcing HOMER to at least use $25 \%$ of the renewable energy was also set as in Figure 15.

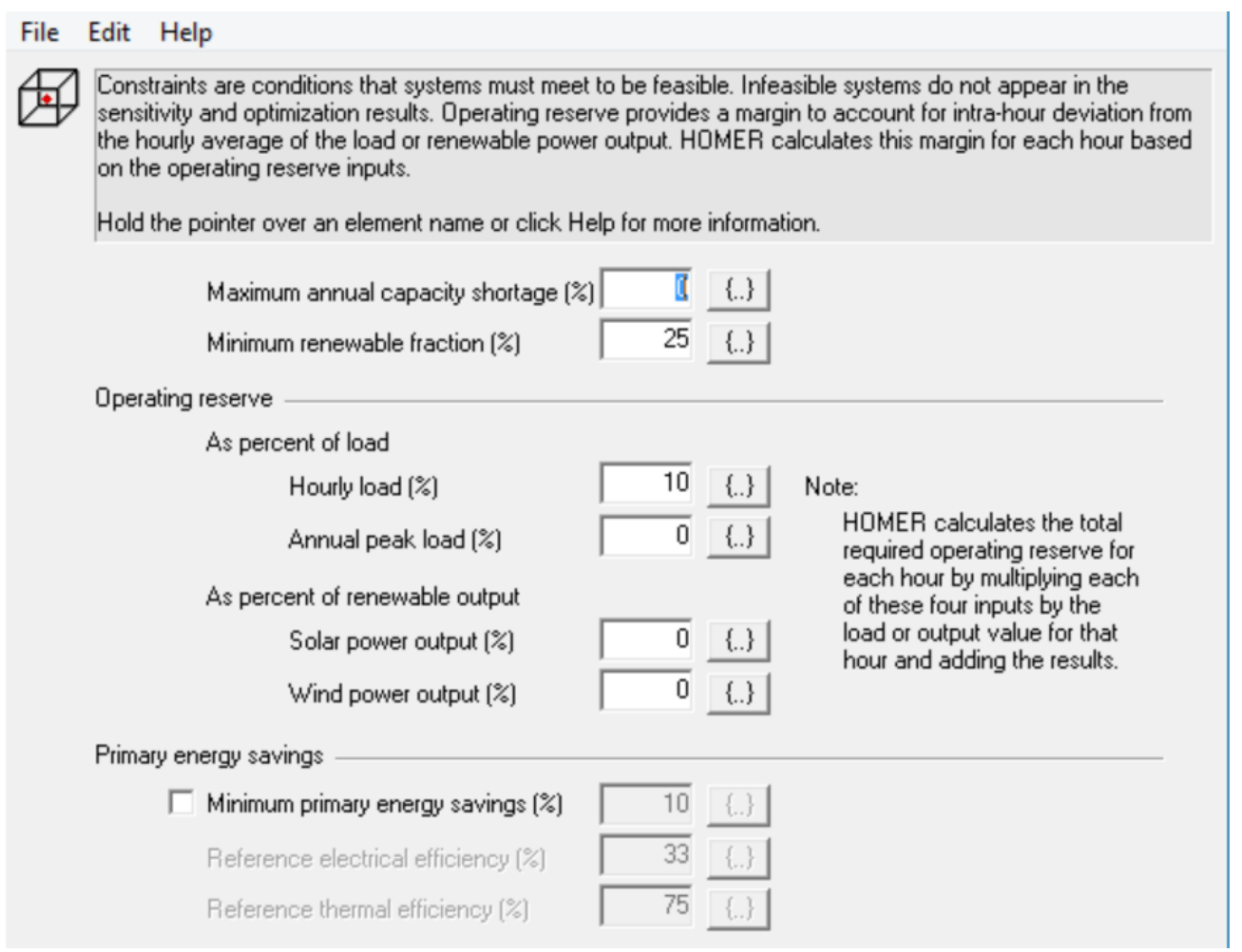

Fig. 15. Renewable energy usage constraints

In Figure 16, the NPC values are negatives, which show the revenues exceed the capital costs. The negative values are reasonable as excess power is sold to the grid. In a trial-and-error methodology, the redundant fuel cells were removed to reduce further the capital costs by only utilizing PV cells as in schematic Figure 17.

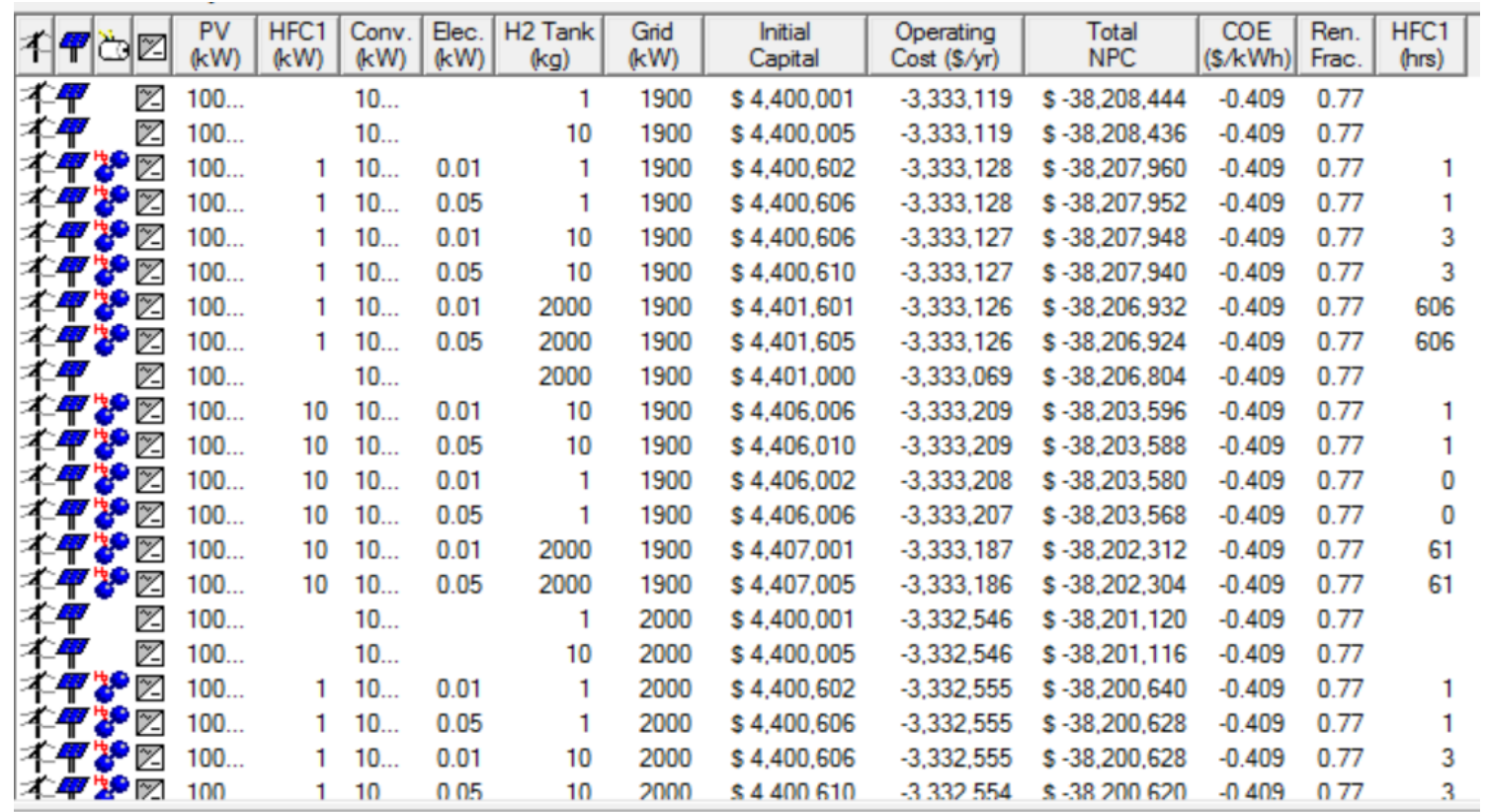

Fig. 16. Simulations results data 


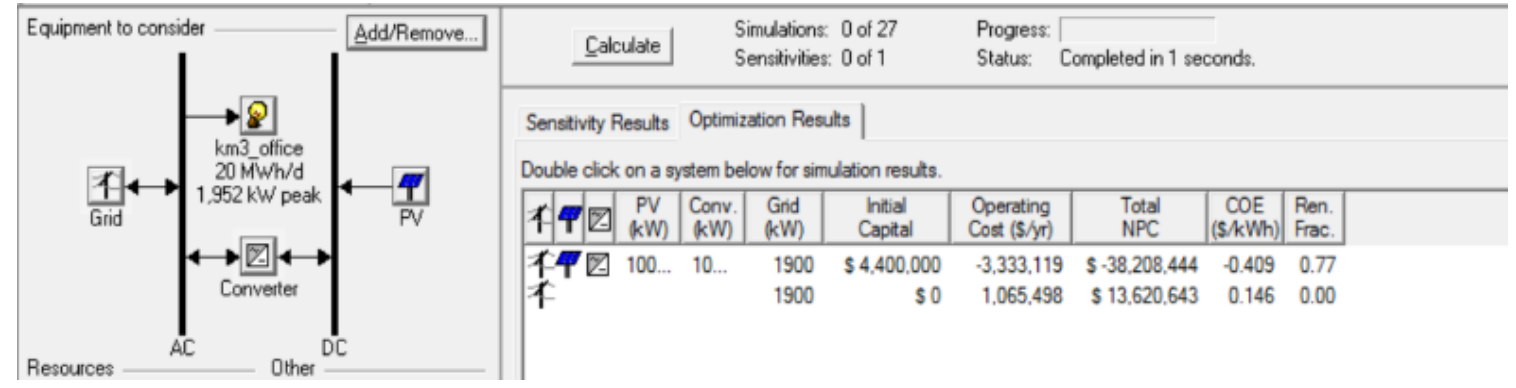

Fig. 17. New modified schematic

The new search spaces were altered to cater to a reasonable size of PV cells and converters, which resulted in more negative values of NPCs where the PV size is now set to a 10,000 kW maximum. The changes for new search spaces are depicted in Figure 18.

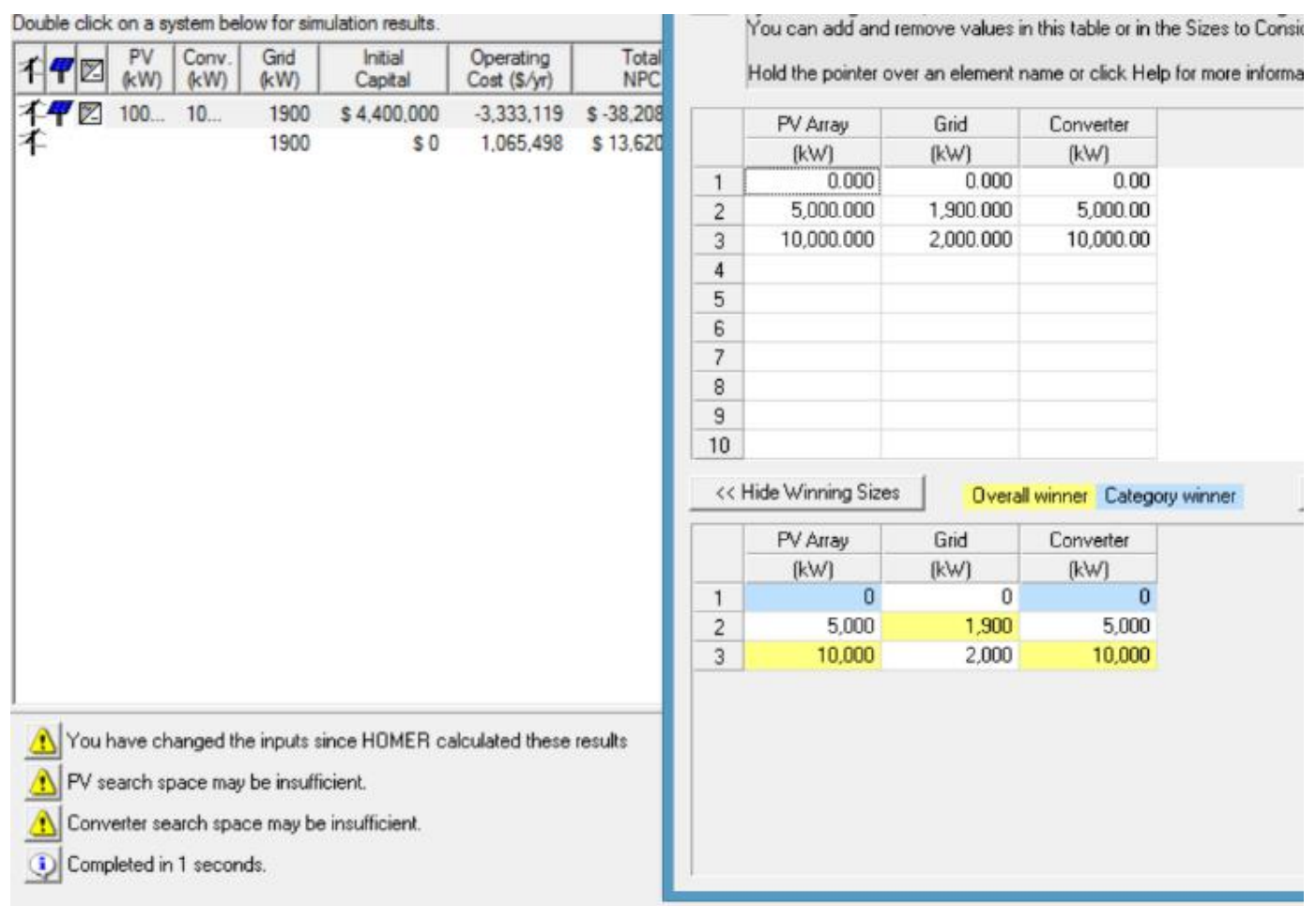

Fig. 18. New search space for simulation

The new results show much higher revenues, as shown in Figure 19. Compared to the grid only sources, the PV and grid alternative gives a return of investment in 1 year.

When checked on the cash flow summary of the HOMER simulation, the grid has negative flows representing the inward cash flow due to the sales of excess energy to the grid based on the feed-in tariff, as illustrated in Figure 20. 


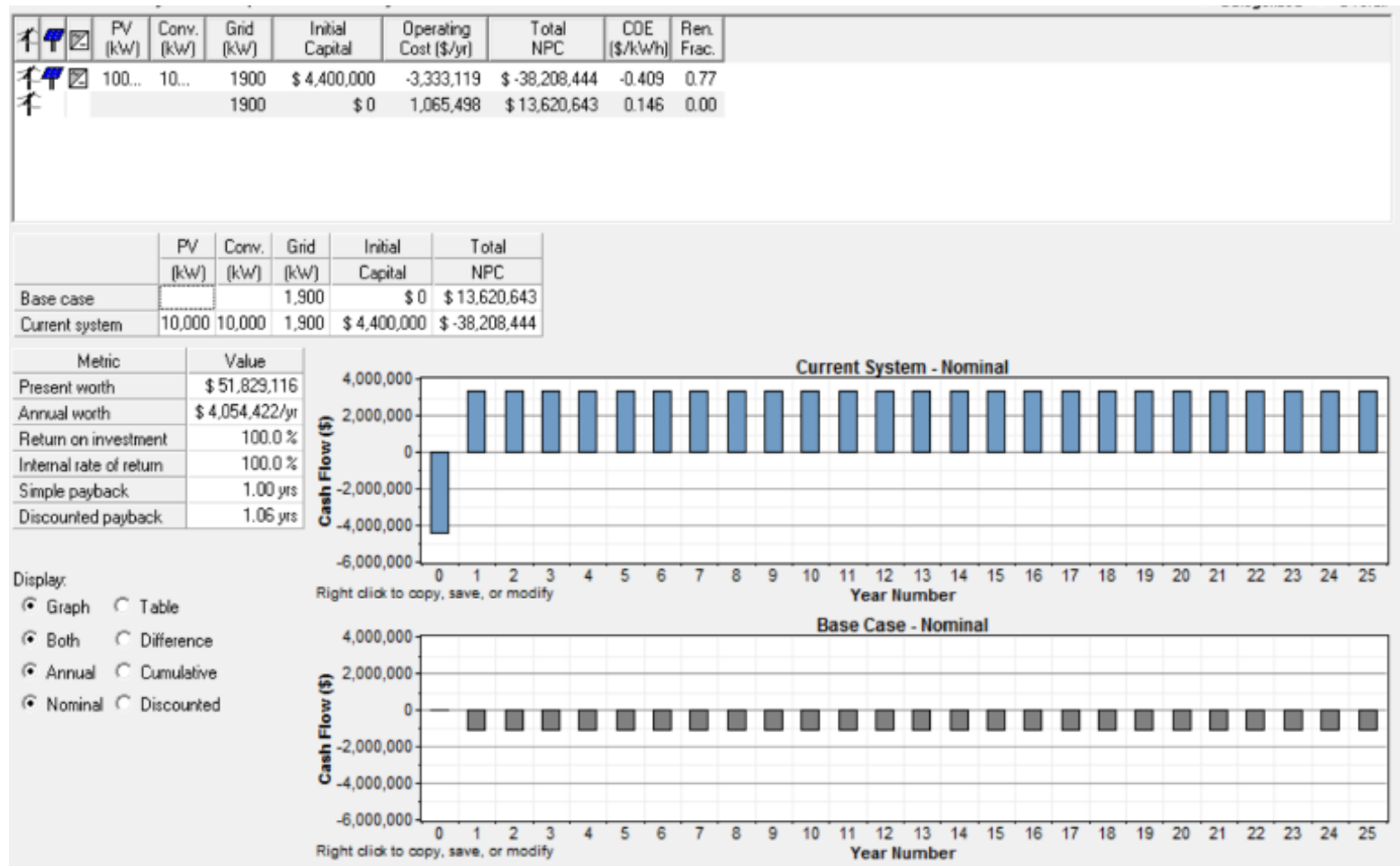

Fig. 19. NPC and payback period

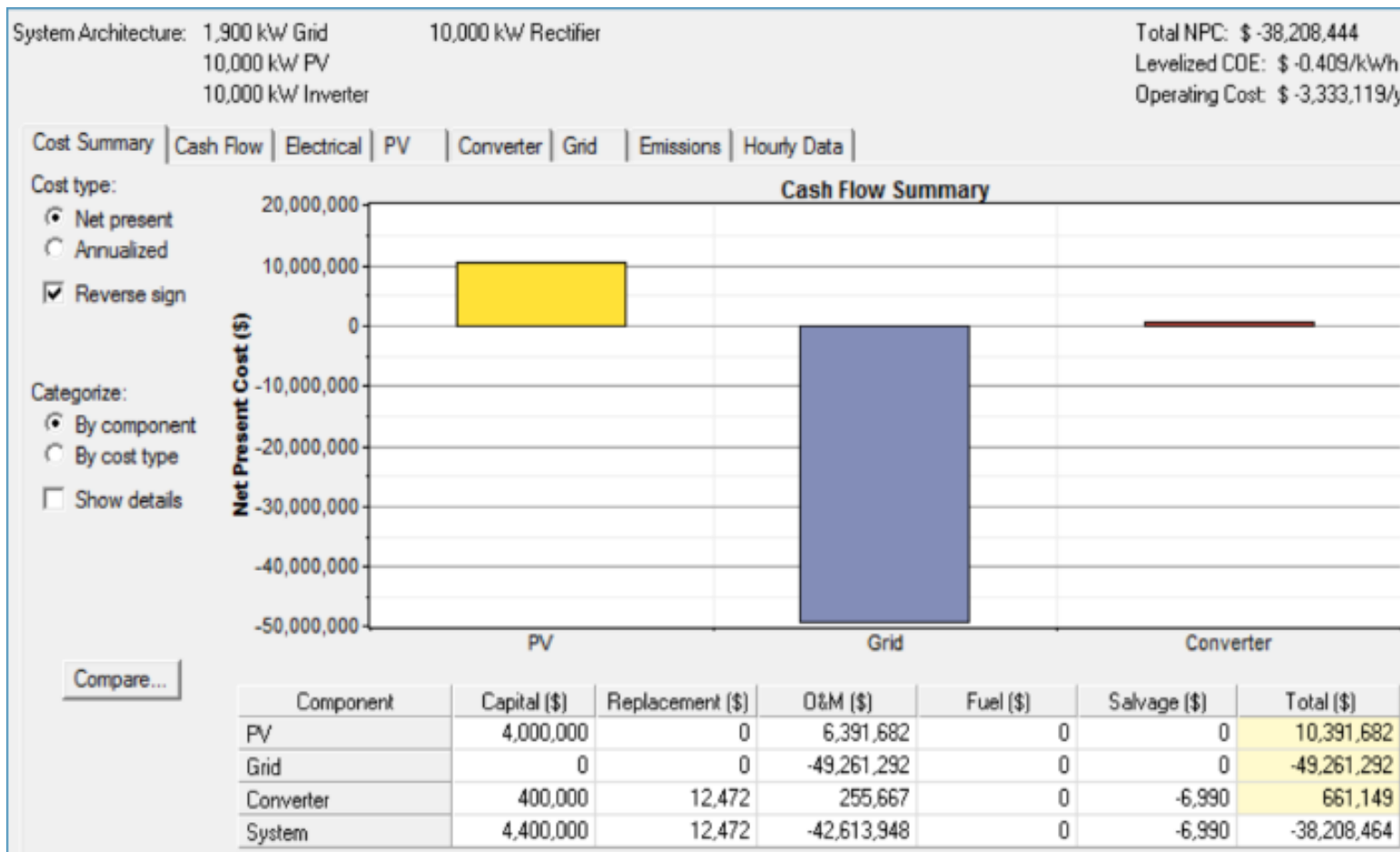

Fig. 20. Cash flow summary 
Electrical consumption by the loads is also mainly from the PV cell arrays. Only about $500 \mathrm{~kW}$ monthly is used from the grid, mostly at night when the grid rates are lower. This usage is illustrated in Figure 21.

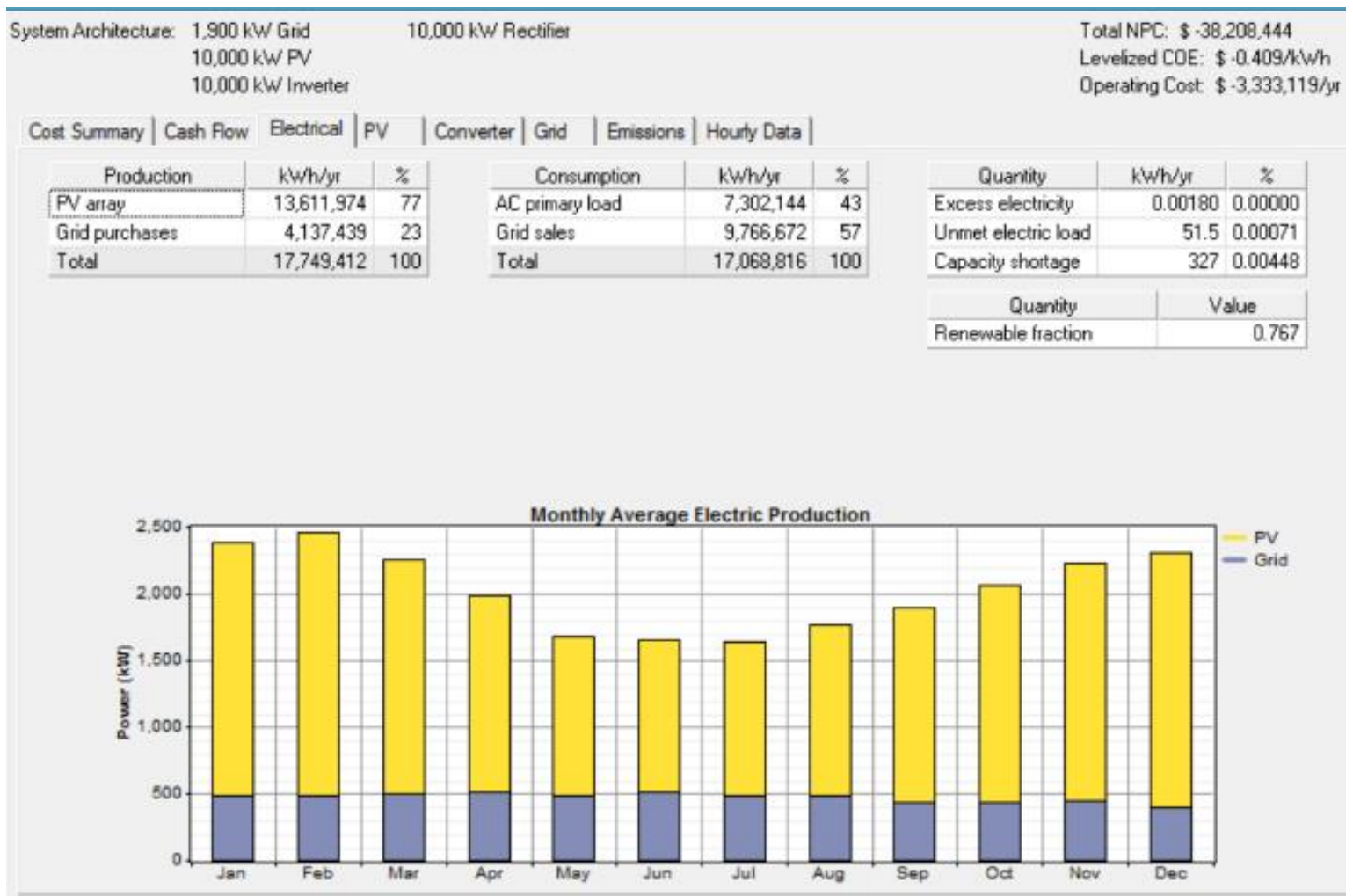

Fig. 21. Electrical consumption by source

A comparison is made between plotting the hourly load parallel to the energy extracted from the grid and PV cells, as shown in Figure 22. Most energy is harvested from the PV cell, as can be seen in the figure.

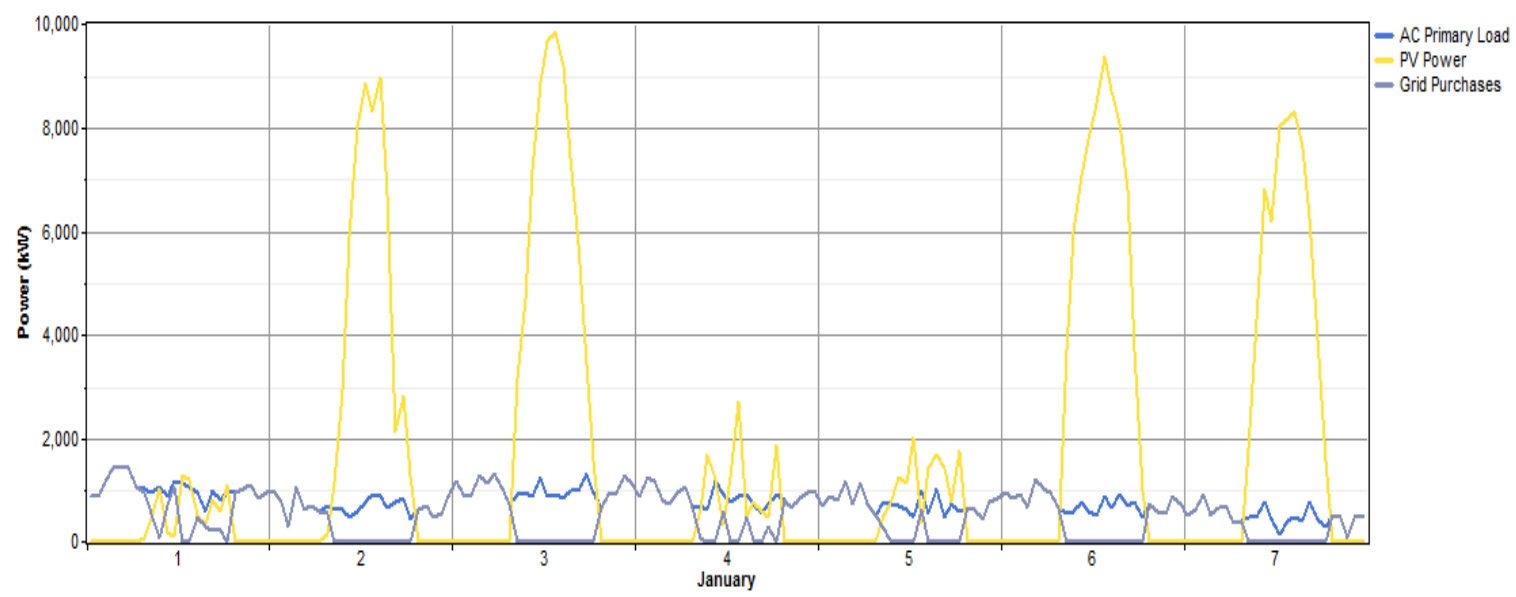

Fig. 22. Hourly electricity load vs PV generations vs Grid purchases

Additionally, the PV generation and Grid Sales are plotted to show the excess PV power is sold in sync with the production on-site, as in Figure 23 below. 
From a green facility point of view, harmful emissions meant to save more power has been sold to the grid, which benefits other users and the environment [19]. The data shown in Figure 24 proves the point as simulated by HOMER.

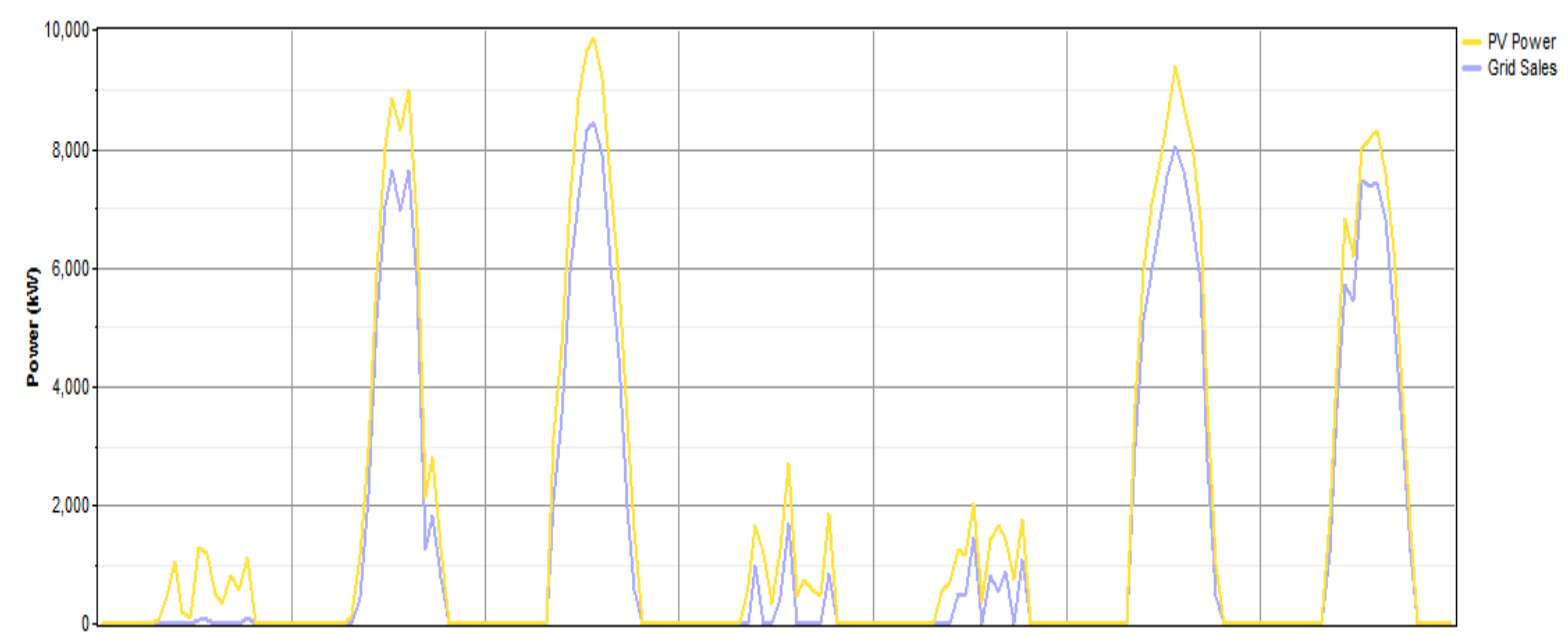

Fig. 23. Hourly PV generation vs Grid sales

\begin{tabular}{|l|r|}
\multicolumn{1}{|c|}{ Pollutant } & Emissions $[\mathrm{kg} / \mathrm{yr}]$ \\
\hline Carbon dioxide & $-3,557,676$ \\
\hline Carbon monoxide & 0 \\
\hline Unburned hydrocarbons & 0 \\
\hline Particulate matter & 0 \\
\hline Sulfur dioxide & $-15,424$ \\
\hline Nitrogen oxides & $-7,543$ \\
\hline
\end{tabular}

Fig. 24. Gases emissions

\section{Discussions}

The Net Present Cost (NPC) is the lifecycle cost of operating any system. The lowest NPC for any configurations means the most cost-efficient approach a building owner may adopt to run systems. Negative values represent higher revenues or return of investment by selling excess power to the grid. The simulation chose a winner based on the input parameters by discarding the Fuel Cell input. It is understandable due to its high cost/power rating investment in fuel cell systems. The industry is yet to find a more cost-effective system to produce bulk Hydrogen. It may take several more years as research is still in the early stages.

As the system's technology, or the photovoltaic cells, evolves into the future, it is forecasted that the running cost would be lower as the prices of the cells may decrease. This pattern is similar to all electronic types of equipment around the world.

\section{Conclusions}

In conclusion, investing in PV or photovoltaic cells for this $\mathrm{KM} 3$ building is most viable compared to other renewable energy systems. An initial capital cost of almost 5 million USD is required, but the payback may be seen in one year. When simulated in HOMER to yield the feasibility of such hybrid installations, it has been shown that the fuel cells are less utilized than the photovoltaic cells. The 
winning configuration has not used even a single kg of Hydrogen due to the high capital cost of the fuel cell and less return of investment spanning more extended periods.

From a practical point of view, the storage of Hydrogen and pipeline may also be an inhibiting factor. In contrast, the photovoltaic cells may seem a more reasonable source by taking advantage of the nature of the building, which has flat rooftops and ample open parking space.

The facility may be used as a secondary power plant to supply power to neighbourhoods in a distributed generation system concept.

\section{Acknowledgement}

The authors would like to thank the Ministry of Health, Malaysia, and University Sains Malaysia for making available the Short-term Grant (304/PPBGN/6313115) and study scholarship, respectively, for this paper to be published.

\section{References}

[1] Energy Commission of Malaysia. National Energy Balance 2015. Suruhanjaya Tenaga (Energy Commission), 2017.

[2] Energy Commission of Malaysia. Malaysia Energy Statistics Handbook 2018. Suruhanjaya Tenaga (Energy Commission), 2019.

[3] Fei, Li, Suocheng Dong, Li Xue, Quanxi Liang, and Wangzhou Yang. "Energy consumption-economic growth relationship and carbon dioxide emissions in China." Energy Policy 39, no. 2 (2011): 568-574. https://doi.org/10.1016/i.enpol.2010.10.025

[4] Mohammed, Omar Hazem, Yassine Amirat, Mohamed Benbouzid, and Adel A. Elbaset. "Optimal design of a PV/fuel cell hybrid power system for the city of Brest in France." In 2014 First International Conference on Green Energy ICGE 2014, pp. 119-123. IEEE, 2014. https://doi.org/10.1109/ICGE.2014.6835408

[5] O'hayre, Ryan, Suk-Won Cha, Whitney Colella, and Fritz B. Prinz. Fuel cell fundamentals, 2nd edition. John Wiley \& Sons, 2006.

[6] Wildi, Theodore. Electrical machines, drives, and power systems, 5th edition. New Jersey: Upper Saddle River (2002).

[7] Curd, Eric F., and Christopher Anthony Howard. Introduction to Building Services. Macmillan International Higher Education, 1996. https://doi.org/10.1007/978-1-349-13298-0

[8] Chadderton, David V. Building services engineering. Routledge, 2013. https://doi.org/10.4324/9780203121320

[9] Hall, Fred, and Roger Greeno. Building services handbook. Routledge, 2017. https://doi.org/10.4324/9781315276977

[10] Louwen, Atse, and Wilfried van Sark. "Photovoltaic solar energy." In Technological Learning in the Transition to a Low-Carbon Energy System, pp. 65-86. Academic Press, 2020. https://doi.org/10.1016/B978-0-12-818762-3.00005$\underline{4}$

[11] Arief, Yanuar Z., Nur Anisah Aziera Abdul Halim, and Mohd Hafiez Izzwan Saad. "Optimization of hybrid renewable energy in Sarawak remote rural area using HOMER software." In 2019 International UNIMAS STEM 12th Engineering Conference (EnCon), pp. 1-5. IEEE, 2019. https://doi.org/10.1109/EnCon.2019.8861255

[12] Rahman, Saifur, and Kwa-sur Tam. "A feasibility study of photovoltaic-fuel cell hybrid energy system." IEEE Transactions on Energy Conversion 3, no. 1 (1988): 50-55. https://doi.org/10.1109/60.4199

[13] Raiashekara, Kaushik. "Hybrid fuel cell strategies for clean power generation." In 2004 IEEE Industry Applications Conference (39th IAS Annual Meeting), pp. 2077-2083. 2004.

[14] Khattak, Muhammad Adil, Mohammad Azfar Haziq Ayoub, Muhammad Ariff Fadhlillah Abdul Manaf, Mohd Faidhi Mahru, Mohd Ridwan Mohd Juhari, Mira Idora Mustaffa, and Suhail Kazi. "Global energy security and European Union: A review." Journal of Advanced Research in Applied Sciences and Engineering Technology 11, no. 1 (2018): 64-81.

[15] Wang, Caisheng, and M. Hashem Nehrir. "Power management of a stand-alone wind/photovoltaic/fuel cell energy system." IEEE Transactions on Energy Conversion 23, no. 3 (2008): 957-967. https://doi.org/10.1109/TEC.2007.914200

[16] Khattak, Muhammad Adil, Nurul Syahrizzat Mohd Yasin, Hannah Natasha Andjani, Puteri Nurailah Husna Mohd Tajuddin, Sakeshraj Narajah, See Zhi Fei, Soh Ann Ting, and Suhail Kazi. "Global energy security and North America: A review." Journal of Advanced Research in Applied Sciences and Engineering Technology 11, no. 1 (2018): 82-98. 
[17] Trifkovic, Milana, Mehdi Sheikhzadeh, Khaled Nigim, and Prodromos Daoutidis. "Modeling and control of a renewable hybrid energy system with hydrogen storage." IEEE Transactions on Control Systems Technology 22, no. 1 (2013): 169-179. https://doi.org/10.1109/TCST.2013.2248156

[18] Bakri, Mohd Azwan Mohd, J. Salmah, S. Abd Rahim, and K. Norman. "A study on Agro-Hybrid Farm Vehicle with Small Onboard Solar Photovoltaic for Herbicide Spraying in Oil Palm Plantation." Journal of Advanced Research in Applied Sciences and Engineering Technology 17, no. 1 (2019): 61-77.

[19] Soon, Willie, Sallie L. Baliunas, Arthur B. Robinson, and Zachary W. Robinson. "Environmental effects of increased atmospheric carbon dioxide." Climate Research 13, no. 2 (1999): 149-164. https://doi.org/10.3354/cr013149 